\title{
EQUITY FINANCING FOR PUBLIC CORPORATIONS: REASONS AND METHODS TO ENCOURAGE IT
}

\author{
JoHN Floegel $\dagger$
}

\section{INTRODUCTION}

Leveraged buyouts ("LBOs") and takeovers of American corporations have become favorite topics of discussion among legal and economic scholars ${ }^{1}$ and favorite games of choice among lawyers and businessmen. $^{2}$ These LBOs and takeovers present policy makers with an intriguing dilemma because of the persuasiveness of both their potential benefits and their harmful effects. Corporate takeover specialists often succeed in unseating ineffective management and in allocating resources more efficiently by divesting companies that have become too large and diverse of unproductive assets. ${ }^{3}$ At the

† B.A. 1987, Georgetown University; J.D. 1990, University of Pennsylvania. This Comment is dedicated to my parents and Richard B. Moller for their guidance and inspiration.

1 See, e.g, Andre, Tender Offers for Corporate Control: A Critical Analysis and Proposals for Reform, 12 DEL. J. CoRp. L. 865, 867 (1987) (proposing federal legislation to maximize shareholder interests in the hostile takeover context); Booth, Management Buyouts, Shareholder Welfare, and the Limits of Fiduciary Duty, 60 N.Y.U. L. REv. 630, 63945 (1985) (discussing issues of fiduciary duty that arise in the context of buyouts); Bratton, Corporate Debt Relationships: Legal Theory in a Time of Restructuring, 1989 Duke L.J. 92, 143-58 (analyzing the changing legal conceptions of the relationship between debtholder and corporate issuers); Coffee, The Uncertain Case for Takeover Reform: An Essay on Stockholders, Stakeholders and Bust-ups, 1988 WIs. L. REv. 435, 435 (arguing for state regulation to encourage a more equitable sharing of takeover gains with stakeholders); Easterbrook \& Fischel, The Proper Role of a Target's Management in Responding to a Tender Offer, 94 HARv. L. REv. 1161, 1161 (1981) (proposing a passivity thesis for target management premised on the assumption that antitakeover maneuvers decrease shareholder wealth); Gilson \& Kraakman, Delaware's Intermediate Standard for Defensive Tactics: Is There Substance to Proportionality Review?, 44 Bus. LAw. 247, 248 (1989) (advocating the Unocal test's intermediate substantive standard for review of directors' actions in a takeover); Lipton, Corporate Governance in the Age of Finance Corporatism, 136 U. PA. L. REv. 1, 6-7 (1987) (warning that the takeover boom is ushering in a dangerous new age of corporate governance); Comment, Judicial Review of Antitakeover Devices Employed in the Noncoercive Tender Offer Context: Making Sense of the Unocal Test, 139 U. PA. L. REv. 225, 227-29 (1989) (discussing the Unocal test's failure to provide a coherent framework for assessing the legitimacy of antitakeover devices).

2 See generally J. Brooks, The Takeover Game (1987) (discussing the evolution of takeover activity on Wall Street); B. Burrough \& J. Helyar, Barbarians at the Gate (1990) (recounting the battle to takeover RJR Nabisco).

3 See Edgar v. MITE Corp., 457 U.S. 624, 643 (1982). Justice White, writing for 
same time, however, the "takeover artists" cut jobs and salaries, ${ }^{4}$ inject unprecedented high levels of debt into companies, ${ }^{5}$ and often are accused of not being committed to the long-term growth and stability of the enterprises they acquire. ${ }^{6}$ Thus, these takeovers result in both social benefits and social costs. ${ }^{7}$

In analyzing corporate acquisition regulation, it is essential to isolate the point where the social costs of these transactions, in terms of displacement and risk that the economy as a whole is forced to bear, outweigh their social benefits. At this point, preserving communities and jobs and insuring the long-term financial health of the country overshadow the goals of proper resource allocation and ousting entrenched, inefficient management. ${ }^{8}$

Corporate acquisition regulation, however, is not the only finan-

the Court, recognized three potential benefits of takeovers: (1) shareholders' "opportunity to sell their shares at a premium," (2) "[t]he reallocation of economic resources to their highest valued use, a process which can improve efficiency and competition," and (3) "[t] he incentive [for] . . . incumbent management to perform well so that stock prices remain high." Id. A recent study examining both failed and successful buyouts confirms that buyouts generally do increase efficiency: manufacturing plants recently a.cquired in leveraged transactions increased productivity at a rate 14 percent higher than those which were not bought out. See Passell, Buyout Fever: The Patient Lives, N.Y. Times, Dec. 13, 1989, at D2, col. 1.

4 See Lipton, supra note 1, at 25-26. In one poignant example, Owens-Corning cut its workforce from 28,000 to 15,000 , as part of a restructuring to fend off a takeover attempt by Wickes Corporation in 1986. See O'Brien \& Kline, An Rx for Jobs Lost Through Mergers, N.Y. Times, Fieb. 22, 1987, § 4, at 23, col. 2.

5 See Lipton, supra note 1, at 20 ("Abusive takeovers have increased the amount of debt in our economy to extraordinary proportions."). During the recent economic expansion, debt of United States ronfinancial corporations has increased by $\$ 840$ billion, while equity has decreased by $\$ 300$ billion. Interest on the debt totals twenty-six percent of internal cash How, an all-time high. This "decapitalization" of United States industry is due, in large part, to mergers and LBOs. See Kaufman, Halting the Leverage Binge, InSTTUUTIONAL InvEsToR, Apr. 1989, at 23.

6 See Hayes \& Abernathy, Managing Our Way to Economic Decline, Harv. Bus. Rev., July-Aug. 1980, at 67, 68-70 (noting that American corporations have sacrificed longterm investments in bringing new ideas to market). In the Owens-Corning restructuring, described supra note 4 , the company cut research and development spending in half and fired 480 research employees. See Willoughby, What a Raider Hath Wrought, ForBes, Mar. 23, 1987, at 56.

7 See Reich, Leveraged Buyouts: America Pays the Price, N.Y. Times, Jan. 29, 1989, $\$ 6$ (Magazine) at 32, 36 ("To the extent that they allocate capital efficiently to where it can be most productive, [LBOs] make our economy perform better. But . . . one must ask whether these benefits are worth what we are paying for them, in terms of both direct costs and future productivity.").

8 This is not to say that the preservation of communities and the financial good health of the country are conditions that cannot exist when there is proper resource allocation and efficient management. It is only when the framework regulating corporate finance distorts the economic choices, as it presently does, that these two sets of conditions become, to a degree, mutually exclusive. 
cial concern on policymakers' agenda. Another major economic issue demanding legal attention is foreign participation in the American marketplace. Modern consumers perceive that the Japanese produce higher-quality durable goods, particularly cars, than do Americans, and this perception is not without sound foundation. ${ }^{9}$ Moreover, Japan has surpassed the United States in several frontier technologies, including superconductors and high definition television. $^{10}$ One does not need sophisticated marketing acumen to understand that superior products in mature industries and a technological edge in developing ones leads to an increase in market share. As a result, even ignoring any unfair trade practices, the American trade imbalance has remained at intolerable levels. ${ }^{11}$

Furthermore, the Japanese consumer's high individual savings rate relative to her American counterpart has contributed to an increasing American dependence on Japanese capital to finance investment activity in the United States. ${ }^{12}$ This combined influx of

9 See Rights and Wrongs of Blaming Japan, N.Y. Times, Oct. 16, 1989, at A20, col. 1 (noting that American consumers believe Japan manufactures higher quality durable goods). The Japanese have captured over $20 \%$ of the U.S. automobile market and have abided by "voluntary" quotas to avoid further inroads. See House, The '90s E' Beyond: Though Rich, Japan Is Poor in Many Elements of Global Leadership, Wall St. J., Jan. 30,1989 , at Al, col 1 .

10 See House, supra note 9, at A8 (stating that "many businessmen . . envy Japan's technological prowess," especially their "feats on the frontiers of high technology"). The Japanese edge in high definition television has prompted cries by U.S. companies for government support. Japanese success in superconductors led to the formation of an American collaborative effort, the now-defunct U.S. Memories, Inc. See Clark, What Strategy Can Do for Technology, Harv. Bus. REv., Nov.-Dec. 1989, at 94, 96; Pollack, Memory Chip Cooperative Is Officially Declared Dead, N.Y. Times, Jan. 16,1990 , at D1, col. 1 .

11 The United States trade deficit for 1988 was $\$ 137.34$ billion, down from $\$ 170.32$ billion in 1987. See Stout, Trade Picture Isn't Improving, Analysts Say, Wall St. J., Feb. 21, 1989, at A2, col. 2. For the first 11 months of 1989, the trade deficit eased by $\$ 6$ billion, to $\$ 101.7$ billion, compared to the same period in 1988. See Trade Gap Widened in November, N.Y. Times, Jan. 18, 1990, at D1, col. 6. Analysts attribute the trade problem to "a very serious competitive problem in the country" and propose several solutions, including improving the quality of American products, increasing the productivity of the American worker, and keeping the dollar exchange rate low. See Stout, supra, at A2. Japanese officials advise the United States to invest in research and development, upgrade education, close the Federal budget deficit, and encourage saving. See Weisman, Japan, Weary of Barbs on Trade, Tells Americans Why They Trail, N.Y. Times, Nov. 20, 1989, at A1, col 3. U.S. legislators are considering specific proposals to promote saving, including one to encourage use of Individual Retirement Accounts. See Nash, Persuading Americans To Save, N.Y. Times, Dec. 17, $1989, \S 3$, at 1 , col. 4 .

12 The United States savings rate, as a percentage of disposable income, is now $4.2 \%$, far below the $16 \%$ Japanese rate. See Sebastian, Baby Boomers Find It Hard to Save Money: Will They Do It Later?, Wall St. J., Feb. 13, 1989, at A1, col. 6. There is 
foreign goods and foreign capital contributes greatly to two other domestic burdens: the budget deficit, which puts upward pressure on real interest rates, ${ }^{13}$ and the decline of the dollar in terms of both relative value and international prominence. ${ }^{14}$ It is not surprising, then, that as a result of all of these considerations, some observers believe that Japan already has replaced America as the economic leader of the world. ${ }^{15}$

Accordingly, just as many people have concluded that legal steps should be taken to curb takeovers, ${ }^{16}$ so too has there been

reason to expect the American savings rate to increase as the baby boomers reach their savings years, after they have accumulated the necessary durable goods and satisfied their housing needs. See R. Pozdena, The Modern Economics of Housing 117-18 (1988). However, many experts are skeptical that this generation, raised in relatively prosperous times, will save like their predecessors did. See Sebastian, supra, at $\mathrm{Al}$, col. 6 ("Nobody believes it ...").

The low U.S. savings rate cannot finance the steady growth and prolific borrowing that has occurred in the U.S. during the mid-late 1980s. See L. Nevaer \& S. Deck, Corporate Financial Pianning and Management in a Deficit Economy 14-28 (1987). The Japanese have provided the necessary funding to fuel further American growth. They were attracted in the mid-1980s by real estate and equity opportunities and in the last two years by high interest rates on bonds. See id. The Japanese in 1987 had almost $\$ 35$ billion in direct United States investments and were buying $25-30 \%$ of Treasury bond issues. See House, supra note 9, at A8. The danger lies in the dependence; the United States needs Japanese capital to continue growing and funding its deficits. As opportunities open up elsewhere for Japanese investors (in the European Community, for example), however, United States interest rates must rise to retain the capital. See id.; L. Nevaer \& S. Deck, supra, at 21.

13 Interest rates must remain high to attract sufficient foreign capital to fund United States deficits. See Lowenstein, Japan Market Woes Raise Fears of Pullback in U.S., Wall St. J., Jan. 19, 1990, at C1, col. 2 (describing how a rise in Japanese interest rates would result in a reduction of the interest rate spread between the United States and Japan, thereby reducing the incentive for Japanese to put their money in the Unites States). Thus, since the United States began running large budget deficits during the Carter years, real interest rates (long-term interest rate minus the inflation rate) have risen consistently. See L. Nevear \& S. Deck supra note 12, at xii. High interest rates tend to stifle economic growth. See id.

14 The decline of the dollar, from about $180-220$ yen in the early 1980 s to about 145 yen today, see Business Digest, N.Y. Times, Feb. 15, 1990, at D1, col. 1, is a phenomenon related to budget deficits and high interest rates. As foreign exchange markets lose confidence in the dollar because of deficits, United States interest rates must rise to maintain foreign investment. See L. NEVEAR \& S. DECK, supra note 12, at xii.

15 See, e.g., Thank You, Japan, Economist, Dec. 23, 1989, at 12-13 (praising Japan's conduct as the world's biggest creditor and new economic leader); House, supra note 9, at Al (describing the world leadership position Japan has secured through its economic prowess).

16 See, e.g., H.R. REP. No. 2172, 100th Cong., 1st Sess., reprinted in Tender Offer Reform - Part I: Hearing Before The House Committee on Energy and Commerce, 100th Cong., 1st Sess. (1987) (Tender Offer Reform Act of 1987) (proposing regulation of takeover activity, including requiring public disclosure within 24 hours after an entity 
clamor to insulate America from foreign competition. ${ }^{17}$ These protectionist proponents, however, appear to have forgotten that legislation proposed in the face of a threat often fails to consider the evils it may create. ${ }^{18}$ Erecting barriers against foreign competition would harm consumers, choking off the flow of cheaper or higher-quality goods to them, and prompt retaliatory responses from affected nations. It also would halt the growth of a world marketplace, to

acquires more than five percent of the shares of a publicly held corporation, prohibiting certain "greenmail" transactions, extending the minimum offering period for tender offers, and providing the SEC with increased rulemaking authority). Many commentators favor dissuading two-tiered bids, either through regulation or general adoption of poison pills. See Greene \& Junewicz, A Reappraisal of Current Regulation of Mergers and Acquisitions, 132 U. PA. L. REv. 647, 691-93 (1984) (recommending regulation of partial and two-tier tender offers); Lipton, supra note 1, at 69-71 (advocating adoption of a "second generation pill," which includes both a "flip-over" provision to guard against squeeze-out mergers and bust-up takeovers, and a "flip-in" provision, designed to prevent undesired partial acquisitions); Comment, supra note 1, at 269-70 (proposing a reinterpretation of Delaware law that would facilitate the use of antitakeover devices for the first sixty days following an initial tender offer proposal). A number of tax disincentives for takeovers have been proposed. See Sheppard, Should Junk Bond Interest Deductions Be Disallowed? 34 TAx NotEs 1142, 1142-46 (1987) (discussing proposals to eliminate the corporate interest deduction for junk bonds); Reich, supra note 7 , at 32 (recommending allowing deductibility of dividends as well as debt, and disallowing deductibility of interest payments on very large borrowings used to purchase corporate stock); Buffett, How To Tame the Casino Society, Wash. Post, Dec. 4, 1986, at A23, col. 3 (proposing a $100 \%$ tax on trading profits obtained by holding a stock for less than one year). The Treasury Department is currently at work on a plan to eliminate the double taxation of dividends, which Secretary Nicholas Brady believes has encouraged debt-financed takeovers. See Murray, Treasury Seeks To End Double Taxation of Dividends, Mulls Corporate-Levy Rise, Wall St. J., Jan. 16, 1990, at A18. There is also considerable support for intracorporate defenses, such as poison pills.

17 In response to mounting public pressure for such protections, Congress recently enacted the Omnibus Trade and Competitiveness Act, Pub. L. No. 100-418, 102 Stat. 1107 (1988). The Act authorizes Presidential action on trade matters, and commentators suggest the President will be required to use this lever in the future. See Bello \& Holmer, Unilateral Action to Open Foreign Markets: The Mechanics of Relaliation Exercises, 22 INT'L. LAw. 1197, $1197-98$ (1988).

18 For example, the Hawley-Smoot Tariff Act of 1930, Pub. L. No. 71-361, 46 Stat. 590 (1930) (codified as amended at 19 U.S.C. $\$ \S 1202-1662$ (1988)), designed to curb foreign competition, may have helped bring on the Great Depression. See Isaac \& Fein, Facing the Future-Life Without Glass-Steagall, 37 CATH. U.L. REv., 281, 286 n.22 (1988). 
which the beginnings of capitalism in China ${ }^{19}$ and perestroika in the Soviet Union ${ }^{20}$ can be partially attributed.

This sketch of the dangers posed by takeovers and foreign competition highlights the fact that "knee-jerk" tactics will not suffice to counter these dangers. Actions which directly curb takeovers or block foreign competition may be counterproductive. Instead, l?wmakers and academics have the responsibility to determine the root cause of these problems in order to develop a thoughtful remedial strategy. The first questions must be why has there been such an explosion of takeover activity, and why are Japan and other nations now able to dominate the United States in international economic competition?

This Comment proposes a simple answer to these questions: the United States no longer possesses the most efficient economy in the world. This reality manifests itself in many ways, from the decreasing relative productivity of the American worker ${ }^{21}$ to the related erosion of our education system. ${ }^{22}$ Most importantly for purposes of this Comment, the inefficiency of the American economy

19 See Worthy, China Tests its Capitalist Skills, ForTune, Oct. 24, 1988, at 174 (stating that Deng Xiaoping begran a "drive to free the Chinese economy from Communist dogma and ... [Chinese] enterprises are striving to become significant participants in world markets."). 'China, however, has not yet absorbed the full effect of the June 4, 1989 massacre at Tiananmen Square. See Is Hongkong Healing?, INSTrTUTIONAL INVESTOR, Sept., 1989, at 307 (finding that the massacre shook "people's trust in the Beijing government and made it difficult to plan for the future").

20 See Flanigan, The Payoff in Making Soviets Our Customers, L.A. Times, Oct. 8, $1989, \S 4$, at 1 , col. 1 (noting that Soviet-United States economic cooperation facilitates Soviet cultural and political change); Clines, Soviets and 6 U.S. Concerns Sign Trade Pact, N.Y. Times, Mar. 31, 1989, at D4, col. 3 (same).

The recent collapse of the communist regimes in Poland, Hungary, Czechoslovakia, East Germany, and Romania can also be tied to a desire on the part of those peoples to participate in the world marketplace. See Herrhausen, Toward a Unified Germany, N.Y. Times, Jan. 7, 1990, § 3, at 2 (noting that the rapid changes in Eastern Europe are attributable to people "becoming receptive to the Western ideas of democracy and market-oriented systems").

21 See Hayes \& Abernathy, supra note 6, at 69.

22 The Wall Street Joumal recently published a comprehensive report on the current state of American education and its future prospects. It began with the premise that "the U.S. education factory is obsolete," see Graham, Retooling the Schools, Wall St. J., Mar. 31, 1989, at R1, F3, and it concluded that a key element in resolving the problem is for businesses and students to match needs with skills. See Lopez, System Failure, Wall St. J., Mar. 31, 1989, at R12; see also Perry, Saving the Schools: How Business Can Help, ForTune, Nov. 7, 1988, at 42 ("American schools are producing an army of illiterates. Companies that cannot hire enough skilled workers now realize they must do something to save the public schools. Not to be charitable, . . . but to survive."). 
can be traced to improper incentives in the legal regime governing corporate investment choices. This Comment concentrates on the preference that the legal structure creates in favor of corporate internal and debt financing over equity financing. Encouraging corporations to finance projects through equity has considerable economic advantages which largely have been ignored, leading to a perverse legal regime that discourages the use of equity. ${ }^{23}$ This Comment takes issue with the current legal financing structure, exploring two feasible methods for resurrecting the advantages of equity financing. First, Congress and the Securities Exchange Commission must overhaul the securities laws and regulations to remove their current disincentives to issuing equity. Second, Congress and the Internal Revenue Service must eliminate the artificial tax preference afforded to debt and internal financing.

This Comment does not assume that the promotion of equity financing by American corporations alone will correct the inefficiencies in the economy which led to the wave of takeovers and the onslaught of foreign competition. Rather, it attempts to expose a fundamental problem and suggest a legal remedy with real macroeconomic effect. It is easy to point fingers at corporate raiders and foreigners, but it is more difficult to recognize that both groups are responding to the fact that the American economic machine does not efficiently allocate its resources to their highest-valued use. American companies are slow to bring high-quality, affordable products to market, a weakness that the Japanese are exploiting. ${ }^{24}$ Also, the stocks of American companies often are undervalued in relation to the price their assets could bring, a market weakness that corporate raiders are exploiting. ${ }^{25}$ One partial solution to these ills lies in

23 The advantages of equity financing are being demonstrated by Japanese corporations, which are currently undertaking a massive refinancing into equity, in the amount of $\$ 130$ billion in 1988. See Glynn, Fall's Trendiest Fashion: Equity, INSTITUTIONAL INVESTOR, Nov., 1989, at 151, 157. In the first eight months of 1989, Japanese corporations raised more than $\$ 110$ billion, compared with $\$ 20$ billion by American companies. See Sterngold, Japan Leading U.S. in Raising Capital for Corporations, N.Y. Times, Oct. 27, 1989, at Al, col. 6. The new equity money is being used to improve balance sheets, to pay for research and development, and to finance foreign acquisitions. In fact, "[e]quity finance is proving so powerful a lever that the dimensions of Japanese takeovers abroad may be limited only by fear of political backlash - not by any financial constraints." Glynn, supra, at 157.

24 Commentators suggest that the main reason large, technology-based American companies have been lagging behind foreign competitors is that the American companies are less adept at translating an idea into a marketable product. See Markoff, A Prescription for Troubled IBM, N.Y. Times, Dec. 10, 1989, § 3, at 4.

25 See generally Jensen, Eclipse of the Public Corporation, Harv. Bus. Rev., Sept.-Oct. 1989 , at 61 . 
changing the legal rules to encourage using equity markets for financing corporate needs. The reasons why equity financing will improve efficiency, and why adjustments in the tax and securities laws will result in more equity financing, are explained in greater detail below. The threats to America's future economic leadership provide a background for the discussion that follows.

\section{Benefits of Encouraging Equity Financing}

Equity financing enables corporations to raise money by selling ownership interests (represented by shares of stock) to investors. Every corporation is authorized to issue a specified number of shares, ${ }^{26}$ and corporate laws generally are designed to insure that every share is issued at a fair price relative to the assets it represents. ${ }^{27}$ Moreover, in the context of large corporations which are either publicly-held or going public, there are established trading markets which provide a ready pool of buyers for these shares. ${ }^{28}$ The Securities and Exchange Commission ("SEC"), state "Blue Sky" laws, and the exchange markets regulate the actual issuance of shares. The basic objective of most of this regulation is to ensure proper disclosure of material information concerning the stock. ${ }^{29}$ Understanding this economic and regulatory environment, a corporation seeking to obtain outside financing through an equity offering has three general concerns:

1. How do the corporate laws limit the number of shares that the corporation can issue and the price that it can obtain for these shares?

2. Who are the buyers, and what price does the market indicate they are willing to pay?

26 See, e.g., Del. Code ANN. tit. 8, § 102(a)(4) (1983 \& Supp. 1988) (stating that the articles of incorporation must prescribe the classes of shares and the number of shares of each class that the corporation is authorized to issue); REv. ModeL Business CoRP. ACT $\$ 6.01$ (a) (1989) (same).

27 See, e.g., Del. Code AnN. tit. 8, § 153(a) - (b) (1983) (stating that stock with par value must be issued at value ar: least equal to capital, while no-par shares must be issued at a price set by the board of directors); REv. MODEl Business CoRP. ACT $\S 6.21$ (c) (1989) (the Official Comment to this section states that setting the issuance price "involves honest and fair judgments by directors").

28 Major United States markets include the New York Stock Exchange, American Stock Exchange, Over-the-Counter Market, and Pacific Exchange.

29 See S.E.C., The Work of THe Securities and Exchange Commission (1986), (stating that the securities laws were designed to facilitate informed investment analyses and decisions by the investing public, primarily by ensuring adequate disclosure of material information), reprinted in L. SoDERQuIST, SEcurities REgulation 2-3 (2d ed. 1988). 
3. What are the substantive and procedural requirements imposed by the securities laws on a sale of the corporation's shares?

The above discussion is not meant to imply that all equity offerings are alike. Indeed, there are two types of equity issuance. The first is called an initial public offering, and it occurs when a company "goes public," selling its stock on a major exchange for the first time. ${ }^{30}$ The second is called a "seasoned issue," occurring when an established public company sells shares from its supply of authorized but unissued stock. ${ }^{31}$ This Comment focuses only on the latter class of equity offerings, seasoned issues, because their benefits more clearly reflect the basic advantages of encouraging equity financing. It is these public offerings, on major exchanges and by large corporations, that should be facilitated, rather than discouraged, by the tax and securities laws.

\section{A. A Greater Number of Equity Financings by All Public Corporations Would Result in Better Aggregate Capital Allocation}

At present, equity financings represent a negligible percentage of total corporate financing. ${ }^{32}$ The macroeconomic factors discussed in this part, however, suggest that equity issuances should play a significantly greater role in funding corporate projects and expansion.

\section{The Concepts of Efficiency and Capital Allocation}

In a recent article, Professor Lynn Stout laments the time and energy expended on the part of lawmakers, judges, and scholars in enhancing the efficiency of the stock market because, he concludes,

30 See Stout, The Unimportance of Being Efficient: An Economic Analysis of Stock Market Pricing and Securities Regulation, 87 Mrch. L. REv. 613, 646 (1988).

31 See id. The issues are called "seasoned" because a market has already been established in the corporation's stock.

32 See id. at 645 \& n.179 ("Firms rarely use equity issues to raise capital."); Reich, supra note 7, at 32 ("During the 1980's new issues of common stock averaged only about 1 percent of the total stock outstanding; the action was in the 99 percent of shares already in circulation."). Only $\$ 85$ billion in common stock was sold to the public between 1980 and 1984. See Smith, Investment Banking and the Capital Acquisition Process, 15 J. Fin. Econ. 3 (1986). Compare this to the $\$ 5.2$ trillion in outstanding stock that was traded on registered exchanges between 1978 and 1985. See NEW York Stock Exchange, New York Stock Exchange Fact Book 74 (1986).

While Japanese companies raise equity, which is being used to finance "a new industrial revolution" as well as major acquisitions in the United States, American CFOs, by contrast, "remain devotees to the cult of leverage." See Glynn, supra note 23 , at 157. 
market efficiency is insignificant. ${ }^{33}$ Professor Stout admits that due to extensive legislative safeguards and judicial sensitivity to efficiency concerns, the stock market has become an incredibly efficient mechanism for incorporating information into share prices. ${ }^{34}$ The Supreme Court, in fact, has accepted the theory that the stock market is almost perfectly efficient with regard to incorporating currently available information. ${ }^{35}$ But Professor Stout argues that this efficiency is meaningless, and the efforts which produce it wasted, since the market serves almost no capital allocation function. ${ }^{\mathbf{3 6}}$ Addressing seasoned issues, Professor Stout relies on the fact that corporations almost never enter the market for their capital needs. ${ }^{37}$ Accordingly, the perfectly efficient market has very little say in which companies should get money or in which projects companies should finance. ${ }^{38}$

Instead of resting with the criticism that the equity markets go largely unused for corporate financing purposes, Professor Stout further argues that resources are being wasted in maintaining and enhancing market efficiency. ${ }^{39}$ This Comment takes issue with the latter argument. The efficient market is a valuable tool waiting to be employed in the essential process of allocating capital to its most productive use.

Classical economic theorists recognize efficient capital allocation

33 See Stout, supra note 30 , at 618 . The kind of efficiency referred to both in Stout's article and this Comment. is Pareto optimality/Pareto superiority. A resource allocation is Pareto optimal when any possible reallocation to make someone better off necessarily makes someone else worse off. A resource allocation is Pareto superior if it makes someone better off without making anyone worse off. See Coleman, Efficiency, Utility, and Wealth Maximization, 8 HoFsTRA L. REv. 509, 512-13 (1980).

34 See Stout, supra note 30 , at 615-16.

35 See Basic, Inc. v. Levinson, 485 U.S. 224, 241-47 (1988) (acknowledging efficient stock markets in accepting the fraud-on-the-market theory).

36 See Stout, supra note 30 , at 642-56.

37 See id. at 645-51; see also sources cited supra note 32 (stating that American corporations now rarely use the equity markets to raise capital).

38 The activity on the exchanges is comprised almost totally of trading in secondary issues. See supra note 32 . From a pure capital allocation standpoint, this trading is wasteful. See Easterbrook \& Fischel, supra note 1, at $1175 \mathrm{n.38}$ ("Expenditures that influence the distribution of trading gains but do not generate better performance are simple waste.").

39 See Stout, supra note 30, at 696-709. The Supreme Court supports efficiency, even at the expense of other goals. See Dirks v. SEC, 463 U.S. 646, 658 (1983) (refusing to extend insider trading liability because to do so would impair efficiency). It is also clear that the SEC is willing to expend resources on enhancing efficiency. See House Comm. on Energy and Commerce, Insider Trading Sanctions act of 1983, H.R. ReP. No. 355, 98th Cong., 1st Sess. 2, 22 (1983). 
as a prerequisite to economic development. ${ }^{40}$ Hence, the existence of a market mechanism that will determine which projects are likely to produce sufficient benefits, in the form of profits, to warrant financing, is an economic necessity. When capital-allocating markets such as the stock market are efficient, the participants in such markets are able to make the correct decisions about which projects to undertake. The market encourages wise decisions simply by assigning a relatively low cost of capital to those projects which are expected to be successful. The efficiency of this assignment process, however, depends upon correct information rapidly reaching the market participants.

\section{How Capital Is Allocated Among Corporations in Today's Financing Environment}

Large public corporations are the locus of domestic project development. ${ }^{41}$ This concentration of power over capital allocation decisions is a logical evolutionary occurrence, resulting from the economies of scale enjoyed by these large corporations. The function of capital markets in an economic environment dominated by large corporations is to allocate capital properly among large corporations. Thus, it is necessary to examine how the American capital markets presently perform in distinguishing among corporations which need capital to undertake their various projects. The benefits of encouraging the use of the stock market as a means of financing will become evident in comparison.

The two primary means of corporate financing are internal and external, with external financing divided into the subcategories of debt and equity. Internal financing refers to the use of retained earnings to fund corporate projects or expansion, and it is the primary financing choice for American corporations. ${ }^{42}$ Using company money has the primary advantage, from management's perspective, of allowing free choice. Management legally has almost complete

40 See, e.g., R. LiPSEY \& P. STEINER, ECONOMics 63-65 (4th ed. 1975) (arguing that the pricing mechanism of an efficient market enhances social welfare); $P$. SAMUElson, Economics 43-47 (9th ed. 1973) (same).

41 See M. Fox, Finance and Industrial Performance in a Dynamic Economy 337 (1987) (stating that the largest 500 corporations control $75 \%$ of the private sector's assets).

42 See R. Brealey \& S. Myers, Principles of Corporate Finance 312-14 (3d ed. 1988) (illustrating that internal financing dominates sources and uses of corporate funds); Stout, supra note 30 , at $645 \mathrm{n} .178$ ("Retained earnings account for the majority of corporate expenditures. ..."). 
discretion over the use of corporate funds, ${ }^{43}$ so it can invest in projects without interference from outside parties. When employing internal financing, management need not listen to the unsolicited advice of commercial bankers, or, as long as it fulfills its fiduciary duties, the input of shareholders. ${ }^{44}$ Power to make decisions about the future of the company thus vests in management. Since project decision making is concentrated in large corporations, and management makes unfettered investment decisions to the extent it uses the favored method of internal financing, capital allocation decisions are largely within the domain of corporate management.

The disadvantages generated when corporate management comprises the capital allocation "market" are threefold. First, managers do not always act in an economically rational way. Most managers strive for power, and power in the corporate world is symbolized by a company's sheer magnitude. ${ }^{45}$ Thus, managers are driven toward expansion, whether or not this is economically appropriate. $^{46}$ Second, corporate managers often have faulty or incom-

43 See Rev. Model Bus. Corp. Act $\S \S 3.02$ \& 3.05 (1989) (allocating control over corporate finances to management and directors, as opposed to shareholders); Del. Code. ANN. tit. 8, § 144 (1983 \& Supp. 1988) (defining general powers of directors and officers to manage the corporation); N.Y. Bus. CoRP. LAW $\S 701$ (McKinney 1986) (same); see also W. Cary \& M. Eisenberg, Corporations: Cases AND MATERIALS 1361-75 (6th ed. 1988) (noting that corporate law allows management discretion over whether to invest cash or pay it out in dividends).

44 It has long been established that courts may interfere on shareholders' behalf if management acts in bad faith. See Dodge v. Ford, 204 Mich. 459, 170 N.W. 668 (1919). The Dodge court stipulated, however, that courts were not to "interfere in the management [with respect to the financing decision] unless it is clearly made to appear that they are guilty" of violating their duty of loyalty to the shareholders. See id. at 500,170 N.W. at 682 (quoting Hunter v. Roberts, Throp \& Co., 83 Mich. 63, 71,47 N.W. $131,134(1890)$ ).

45 Largely as a consequence of the separation of ownership and control, managers act to increase their personal power and prerogative, even at the expense of the corporation. See A. Berle \& G. Means, The Modern Corporation and Private Property 119-25 (1932). Congressional debate preceding the Securities Act of 1933 (codified as amended at 15 U.S.C. $\$ \S 77 a-77$ aa (1988)) recognized the selfaggrandizement motive of management. See 77 Cong. REc. 2918 (1933) (statement of Rep. Rayburn) (stating that "these few men, proud, arrogant, and blind, drove the country to financial ruin").

Respected economists such as Joseph Shumpeter and Frank Knight pointed out long ago the "empire building" motivation of corporate management. See W. McEachern, Managerial Control and Performance 19 (1975). There is some evidence that management strive:; for size because of the perceived protection from takeover. See E. Herman, Corpofate Control, Corporate Power 101 (1981). The takeover of RJR Nabisco by Kohlberg, Kravis, Roberts may dispel this notion. See Anders, RJR Finale Will Send Money Coursing, Wall St. J., Feb. 9, 1989, at C1, col. 3. (describing KKR's takeover of RJR Nabisco, an enormous conglomerate).

46 There have been instances where corporations have built huge empires, with 
plete information about the full investment spectrum. ${ }^{47}$ Finally, the tax law severely distorts managers' options for the use of corporate funds. Management must choose between the retention and investment of earnings or the dividend disbursement of funds to shareholders. Under current law, earnings that are paid out as dividends to individuals are subject to taxes twice, with both the company and the individual paying income tax. ${ }^{48}$ The second level of tax imposed on dividends drives management to retain earnings and find some way to invest them. In a no-tax world, a corporation would only retain earnings when it could put the money to use more profitably than its shareholders could. But in the real world, corporations withhold earnings to avoid double taxation, thus consciously and rationally misallocating capital.

After internal financing, corporate managers' favorite choice of funding is debt. ${ }^{49}$ Corporations undertake debt financing by selling

management seemingly oblivious to increasing shareholder return. See, e.g., Colvin, The Bigness Cult's Grip on Beatrice Foods, ForTune, Sept. 20, 1982, at 122 (describing Beatrice Foods' low return on shareholder equity, due primarily to the large number of unprofitable companies it owned). The threat of takeover prompted Beatrice ambitiously to divest 52 of its companies, beginning in 1983. See Mesdag, Beatrice's Stock Buy, Fortune, Jan. 9, 1984, at 111. Similarly, the R.J. Reynolds Corporation owned Nabisco for less than five years before Kohlberg, Kravis, Roberts acquired the conglomerate and began dismantling it. See Smith \& Waldman, KKR Assigns Goldman Sachs to Solicit Bids for RJR Nabisco's Del Monte Unit, Wall St. J., Mar. 20, 1989, at A3, col. 2 (noting that "Kohlberg Kravis Roberts \& Co. has launched its plan to sell food assets of RJR Nabisco"); Anders, supra note 45, at Cl (describing KKR's takeover of RJR Nabisco); Purdom, R.J. Reynolds Set to Pay $\$ 4.9$ Billion for Nabisco, N.Y. Times, June 3, 1985, at Al, col. 3 (announcing the 1985 takeover of Nabisco by R.J. Reynolds).

The stock market does not reward expansion solely for the purpose of diversifying away the unique risk of a particular business. The market assumes that shareholders can and do diversify their own portfolios.

47 Some commentators disagree with this premise, arguing that management has superior access to intracorporate information, as compared to the capital market. See O. Williamson, Markets and Hierarchies: Analysis and Antitrust Implications 145-48 (1975). This argument misses the point. The relevant information concerns the entire range of investment opportunities in the marketplace, and capital market participants are the most efficient processors of that information.

Williamson asserts that internal corporate monitoring has become dominant because evolution has proved it most effective. See Williamson, Organization Form, Residual Claimants, and Corporate Control, 26 J. L. \& ECoN. 351, 365-66 (1983). He fails to account for the fact that this evolution was responding to disclosure requirements and tax laws that favored (and continue to favor) internal control mechanisms.

48 See Murray, supra note 16 , at 18.

49 See Kaufman, supra note 5, at 23 (noting that companies prefer debt to equity primarily because of double taxation of dividends); Myers, The Capital Structure Puzzle, 39 J. FIN. 575, 581-82 (1984) (noting that corporate managers prefer debt over 
bonds to investors or by obtaining long-term loans from financial institutions. ${ }^{50}$ In either case, corporate management allows another party to influence the capital allocation decision. This would be beneficial if the bankers and bond investors (or rating services, which perform the research upon which unsophisticated investors rely) bring more information to corporate investment decision making. Unfortunately, the reality of debt financing paints a different picture.

In terms of capital allocation, the disadvantages of debt financing closely parallel the disaclvantages associated with internal financing. Although creditors perform some external assessment of a particular corporation's capital project track record, ${ }^{51}$ the nature of the inputs they use to make the assessment reveals its limited usefulness. The credit assessment focuses almost exclusively on assigning an interest rate to the debt of a corporation based primarily on two factors: (1) prevailing interest rates and (2) risk of bankruptcy or default. ${ }^{52}$ Prevailing interest rates, however, are not company-specific, ${ }^{53}$ so they do not serve to distinguish among companies competing for funds. This leaves the risk of bankruptcy as the major factor that creditors use to assign a relative cost of capital to a debtor. Thus, the contribution of large creditors to the capital allocation process is limited merely to exposing those corporations which are destined for failure. ${ }^{54}$ Beyond this point, the selection between

equity financing); see also M. Fox, supra note 41 , at 270-82 (discussing internal, debt, and equity financing, and the cost:s and benefits associated with each method).

50 Short-term bank loans for liquidity purposes are excluded from this discussion.

51 A prospective debtholder's assessment of the future growth prospects of a major corporation is not as detailed as that undertaken by stock analysts. This is because bond rating agencies lack the incentive to investigate closely the growth potential or growth history of the company. See Levmore, Monitors and Freeriders in Commercial and Comporate Settings, 92 YALE L.J. 49, 58-59 (1982).

52 See Note, Auctioning New Issues of Corporate Securities, 71 VA. L. REv. 1381, 140304 (1985).

53 Most banks use the universally available prime rate, to which they add a risk premium, in computing what interest to charge their corporate customers. See $\mathbf{R}$. BREALEY \& S. MYERS, supra note 4\%, at 307.

54 This limited perspective by creditors regarding a borrowing corporation's success is based on sound economic reasoning. Creditors are entitled to receive only a fixed payment (principle plus interest) from the corporation on its loan. If the corporation has the financial strength to make those fixed payments, it is generally irrelevant to the creditor the rate of return the corporation receives on its investment of the loan proceeds. On the other hand, shareholders are residual claimants to the corporation's profits, so they "own" any money earned by the corporation over and above that which is needed to pay all of the corporation's other obligations. Thus, they have an incentive to maximize this "residual." See Easterbrook \& Fischel, Voting 
alternative investment choices is left with the same group that controls internal financing deployment: management.

Almost all financing by established United States corporations is done with either internal or debt financing. ${ }^{55}$ But as the discussion above reveals, neither method effectively distinguishes among solvent corporations with regard to their future prospects, a function that is absolutely necessary for efficient capital allocation. Hence, economic policymakers must find and encourage a more efficient mechanism to perform this crucial function. Fortunately, they need search no further than the remaining established source of corporate financing.

\section{Advantages of Equity Financing}

Capital allocation would be improved markedly if corporations were encouraged to finance their expansion or operations by issuing stock on the equity market. ${ }^{56}$ An understanding of the mechanics of capital allocation through the equity market is necessary before the specific advantages can be enumerated and understood. Indeed, it is within the mechanics of the equity market where equity's advantages lie, dormant and largely unexploited.

According to at least one widely accepted theory, investors price shares of stock according to the corporation's expected future return, ${ }^{57}$ discounted for nondiversifiable risk. ${ }^{58}$ Many factors, both systemic and company-specific, are considered in this equation, and differences in opinion among market participants about the correct price of stock are resolved through trading. Simply put, those inves-

in Corporate Law, 26 J.L. \& Econ. 395, 403 (1983) (discussing shareholders' incentive in making discretionary decisions relating to corporate income).

55 See supra notes $42 \& 49$.

56 Henry Manne first pointed out that corporations are disciplined in their investment activity by capital market competition. See Coffee, Regulating the Market for Corporate Control: A Critical Assessment Of the Tender Offer's Role in Corporate Governance, 84 Colum. L. REv. 1145, 1234-35 (1984). His broad thesis has prompted significant interest mostly in the context of tender offers, however. See id. at 1234 ("Corporations compete . . . in the capital market, where a poor return on the investor's equity may elicit a tender offer.").

57 "Expected return" means the average of all possible returns, each discounted for its probability. See W. Klein, Business Organization and Finance: Legal and ECONOMIC PRINCIPLES 145-46 (1980).

58 See R. BREALEy \& S. MYERS, supra note 42, at 137-40 (describing the Capital Asset Pricing Model, a formula using expected return, defined as anticipated dividends and appreciation produced by the corporation, and "beta", defined as company-specific risk); Gordon \& Kornhauser, Efficient Markets, Costly Information, and Securities Research, 60 N.Y.U. L. REv. 761, 825-27 (1985) (discussing the operation of the CAP-M model, and problems associated with it). 
tors who think the price is too low buy, while those who think the price is too high sell. In this way, the experts reach a consensus about a corporation's future prospects, and the trading price of the company's stock reflects this consensus.

Absent transaction costs, a stock's market price dictates the amount of money a corporation making an equity issue will receive for selling a new share of stock. Assuming healthy trading volume in the company's stock, market investors should be willing to absorb the seasoned (newly issued) shares as readily as they buy the secondary shares because the two are interchangeable. ${ }^{59}$ Moreover, issuing new shares will not depress the per-share stock price, as long as shareholders perceive that the corporation will earn a rate of return on its investment of the new money received commensurate with that earned on the corporation's other investments. ${ }^{60}$ In such an environment, the corporate financing decision involves only deciding how much money is needed, and dividing this total by the market price-per-share to arrive at the number of shares it needs to issue to finance its project.

A corporation's market share-price is thus directly determinative of its cost of capital. For example, postulate two companies with the exact same asset value and current profitability. Assume that despite the identical balance sheets, the market price-per-share of one company, Alpha, is $\$ 50$, and that of the other company, Beta, is $\$ 25$, because the participants in the market expect Alpha's future profitability to exceed Beta's. Thus, the market has assigned a lower cost of capital to Alpha, because it can receive $\$ 50$ by diluting the ownership of its asset base and income stream by only one share. The cost to Beta, in terms of dilution, however, is two times greater.

Further analyzing this hypothetical leads to an understanding of equity financing's capital allocation advantages over internal financing and debt. Because the current conditions of companies Alpha and Beta are identical, the market must have differentiated them based on an expectation that deploying assets in the manner chosen by Alpha will produce a future return (in present value terms) twice that which deploying the same assets in the manner chosen by Beta

59 See E. Mansfield, Microeconomics: Theory and Applications 116-17 (4th ed. 1982) (describing elastic demand, which occurs when goods are similar and can be traded easily).

60 See R. Brealey \& S. MYers, supra note 42, at 316-16 (stating that "dilution" of stock does not occur when "investors know that you can earn an adequate rate of return on the new money"). 
will produce. Accordingly, the market rewards Alpha because it has found a higher valued use for the same assets than has Beta.

One crucial caveat exists regarding the model demonstrated above: the means by which equity financing allocates capital is only advantageous to the means by which internal or debt financing allocates capital if better information is made available through the equity market. In other words, equity financing is not advantageous (1) if the market is not efficient or (2) if market participants do not use the right information in pricing stocks because an insufficient quantum and quality of information reaches its participants.

It is not the purpose of this Comment to prove that the stock market is efficient. The Supreme Court has recognized that the market is efficient with regard to current information, ${ }^{61}$ and most scholars agree. ${ }^{62}$ The fact that the market rapidly incorporates information into share prices, however, says nothing about the quality of that information ${ }^{63}$ or whether enough information is available to allow the market to correctly predict a company's future prospects. Hence, because the stock price is the sole mechanism for allocating capital where equity financing is used, it is necessary to examine the integrity of stock prices.

To examine the integrity of stock prices, a context and a basis for comparison are needed. The context is set by whether a company's stock price reflects the future return on management's investment of corporate assets, as described by the Alpha/Beta

61 See Basic, Inc. v. Levinson, 485 U.S. 224, 245-47 (1988) (acknowledging the integrity of securities markets). An argument for market efficiency may seem to contradict the previous argument that companies are taken over because they are undervalued. The answer to this criticism is that the market has priced the stock to reflect how the assets are deployed; however, the assets may not be deployed efficiently.

62 See R. Brealey \& S. Myers, supra note 42, at 285-89; Barry, The Economics of Outside Information and Rule 10b-5, 129 U. PA. L. REv. 1307, 1315 (1981); Cox, Reflections on Ex Ante Compensation and Diversification of Risk as Faimess Justifications for Limiting Fiduciary Obligations of Corporate Officers, Directors, and Controlling Shareholders, 60 TEMP. L.Q. 47, 52 (1987); Dennis, Materiality and the Efficient Capital Market Model: $A$ Recipe for the Total Mix, 25 WM. \& MARY L. REv. 373, 374 (1984); Dent, Dual Class Capitalization: A Reply to Professor Seligman, 54 Geo. Wash. L. Rev. 725, $741-42$ (1986); Note, Insider Trading and the Corporate Acquirer: Private Actions Under Rule 10b-5 Against Agents Who Trade on Misappropriated Information, 56 Geo. WASH. L. REv. 600, 637 (1988).

63 See Gulf \& W. Indus. v. Great Atl. \& Pac. Tea Co., 356 F. Supp. 1066, 1071 (S.D.N.Y.) (stating that the "whims and caprice of the crowd" are incorporated into share prices), aff'd, 476 F.2d 687 (2d Cir. 1973); see also Shiller, Do Stock Prices Move Too Much to Be Justified by Subsequent Changes in Dividends?, 71 AM. ECON. REV. 421 (1981) (concluding that the stock market's level of volatility is unexplained). 
hypothetical. The basis for comparison is provided by the information brought to bear on corporate investment decisions through both the debt and internal financing processes.

To recap, in the debt financing process, only the systemic factor of prevailing interest rates and the company-specific factor of risk of bankruptcy are considered. ${ }^{64}$ Because this analysis does not involve differentiation premised on future growth potential, ${ }^{65}$ it is based on incomplete information. Moreover, the limited information may be faulty. Thus, both the amount and quality of information incorporated into the price of a company's debt are inadequate.

By comparison, the equity pricing mechanism involves the examination of a much greater quantum of information and contains more safeguards that the information is correct. Equity markets examine all factors which will affect expected future profitability, discounted for nondiversifiable risk. In addition to prevailing interest rates, an important consideration that equity markets have in common with debt markets, these factors include inflation expectations, trade imbalances, economic legislation, new technology, changes in consumer markets and demand, and pending litigation, all assessed in light of the impact these factors have on the business that the particular company conducts. ${ }^{6 \epsilon}$ The company-specific effects can be gleaned from the voluminous disclosures companies are forced to make by the securities laws. ${ }^{67}$ Not only is the amount of information greater, but the quality of the information is ensured by the highly competitive nature of equity trading. ${ }^{68}$ As soon as new information becomes available or old information proves inadequate, market participants trade. The profit motive instills competition in the market, and this ensures that information is complete and accurate. ${ }^{69}$

Equity financing also provides better information about invest-

64 See supra notes $49-55$ and accompanying text.

65 See supra notes $49-55$ and accompanying text. But see T. Sullivan, E. WARREN \& J. Westbrook, As We Forgive DUR Debtors 322 (1989) (stating that creditors frequently decide, when approving loans to a company engaged in a new venture, that the "higher bankruptcy risk is worth the increased profits").

66 See Stout, supra note 30, at 679-80. Indeed, unlike debt markets, "an efficient market [in equity securities] by definition reflects all information," id. at $701 \mathrm{n} .433$, so that equity markets require "massive amounts of information" to work properly. Id. at 701 .

67 See infra notes 98-111 and arcompanying text.

68 Auction-type exchanges usually result in the most economically efficient capital allocation. See Bebchuk, The Case for Facilitating Competing Tender Offers, 95 HARv. L. REv. 1028, 1048 (1982).

69 See supra notes $62-63$ and accompanying text (noting that the market rapidly incorporates current information into stock prices). 
ment decisions than does internal financing. Equity's principal advantage is that investors and professionals can influence a corporation's investment pattern by establishing its share price, thereby breaking the monopoly over capital allocation decisions that corporate managers enjoy when using internal financing. Management must be sensitive and responsive to what investors, through the market, are telling it to do. ${ }^{70}$ Investment professionals thus impose information upon corporate managers which they may not otherwise consider. Because the investing public recognizes when the corporation is investing funds inefficiently ${ }^{71}$ and drives the stock price down (increasing the cost of capital), management is forced to distribute more earnings as dividends. Also, the market tempers the selfaggrandizement motive that drives management to expand corporations even where it is inefficient to do so. ${ }^{72}$ This theory that external market vigilance can affect corporate management behavior ${ }^{73}$ flows into the discussion, undertaken below, of a second benefit of encouraging corporations to resort to the equity market for financing.

70 Other methods of ensuring that management is responsive to the desires of investors include shareholder voting, mandatory disclosure statutes, independent boards, and derivative litigation. See Fischel, The Corporate Governance Movement, 35 VAND. L. REv. 1259 (1982). The assertion here, however, is that none of these is as effective at synthesizing management and stockholder concerns as an equity financing regime. The methods enumerated in this note have little effect on corporate investment planning, while an equity financing regime would have a profound influence on investment decisions.

Such a regime would allow stockholders to influence investment decisions because management would have to go to the market to finance investments. Stockholders would express their views on a proposed investment by trading in the stock, thereby forcing its price higher or lower depending on the quality of the proposed investment. See supra notes 56-60 and accompanying text.

Fiduciary duties are another historical means of making managers accountable to shareholders. Some argue that the existence of these duties demonstrates that the market has failed to impose accountability. See Easterbrook \& Fischel, Corporate Control Transactions, 91 YALE L.J. 698, 700-02 (1982).

71 Stockholders would demand a greater dividend payout when they perceived an opportunity to invest funds at a higher return than the corporation's investments would bring. See supra notes $45-46$ and accompanying text. The corporation, however, would probably not pay the increased dividend because of the double taxation of these payments. See infra notes $141-50$ and accompanying text.

72 See supra notes $45-46$.

73 The market has some effect on managerial decision making today. See Coffee, supra note 56, at 1200 ("[I]nstances of managerial inefficiency or self-dealing will not result in a significant enough discount in the corporation's shares . ...."). A corporation that does not have to resort to the market for financing will not be sufficiently restrained by that market. 


\section{B. A Greater Number of Equity Financings Would Obviate the Need for Some Hostile Takeovers}

The discipline exerted by the equity market over corporate investment decisions would motivate management to base these decisions on the long-term profit potential inherent in a proposed investment. ${ }^{74}$ Management. would be discouraged from pursuing inefficient investment strategies for the purpose of self-aggrandizement because the market would make such strategies prohibitively expensive by lowering the stock price of the company. Similarly, companies that wish to have access to reasonable equity financing would have to take steps to boost their stock prices. They would have to redeploy assets in a. more efficient manner, sell off some of the less profitable assets, or, if necessary, establish a more generous dividend policy. All of these corporate actions would tend to raise stock prices by aligning assets with their most valuable uses, thus producing the same benefits that takeovers generate without the accompanying economic and social dislocations.

Of equal importance, the products of these corporate actions, higher stock prices and more efficiently deployed assets, take away much of the profit motive behind takeovers. Takeovers are largely precipitated by a raider's belief that the corporation's assets are not creating a return commensurate with their potential. ${ }^{75}$ If management were constantly under market pressure to find the right asset allocation, however, this belief would evaporate. A second element of the profit motive driving takeovers is the perception that corporations are not distributing enough money to shareholders. ${ }^{76}$ The tax disadvantage of dividends, combined with management's self-

74 See Coffee, supra note 56, at 1149 n.6 (noting that there are many cases today in which corporations "pay[] too much because management is more interested in increasing the size of its corporation than in maximizing value for shareholders"); Note; The Conflict Between Managers and Shareholders in Diversifying Acquisitions: A Portfolio Theory Approach, 88 YALE L.J. 1938, 1246-47 (1979) (observing that long run investment performance of acquiring companies is generally worse than that of nonacquiring companies, and that the value of acquirers' shares drops an average of two percent at the announcement of an impending acquisition).

75 A Touche Ross survey revealed that bidders are especially attracted to companies with low price-to-assets and price-to-earnings ratios. See Touche Ross \& Co., The Effect of Mergers, Acquisitions, and Tender Offers on American Business: A Touche Ross Survey of Corporate Directors' Opinions 9 (1981). When a company has a low price-to-assets ratio relative to the market, investors expect the company to produce sub-average returns with the assets as currently deployed. When a company has a low price-to-earnings ratio relative to the market, investors expect future earnings growth to be slower than the market average.

76 Bidders seek companies with large cash reserves, high liquidity, and 
aggrandizing goals, support the general corporate policy of retaining earnings, even in cases where shareholders have the ability to invest the funds more profitably. ${ }^{77}$ Corporate raiders recognize and seize upon these situations of inefficient cash retention. In the same way, raiders take advantage of situations in which corporations maintain nonproductive assets. ${ }^{78}$ These situations are many, because management, which is in control of the capital allocation process, ${ }^{79}$ does not always accurately perceive the desirability of alternative external investments or realize that selling assets and paying dividends are viable alternatives. The supervision of the equity market, however, would diminish the takeover profit motive inherent in inefficient cash retention or asset maintenance. This is because the market would raise the cost of capital for a corporation that did not pay dividends or refused to sell off unprofitable assets. Corporations would therefore have to alter their investment strategies, pay higher dividends, and reallocate their assets. This natural response to market-imposed "rules" removes some of the most powerful forces driving takeovers.

Furthermore, encouraging companies to undertake equity financing would reduce the possibility of "bust-up" takeovers, while promoting the same asset allocation benefits of these takeovers. ${ }^{80}$ Many hostile takeovers produce economic advantages associated with trimming wasteful staff, assets, and production capacity. ${ }^{81}$ Under an equity financing regime, this process still would occur, demanded by the market rather than imposed by the hostile raider. Corporate management will have to respond to market pressure, ${ }^{82}$

substantial unused debt capacity. See id. at 13. These factors all dicate a company's potential to increase payouts to its owners.

77 See Staff of Joint Comm. on Taxation, Federal Income Tax Aspects of Corporate Financial Structures 85 (Jt. Comm. Print 1989) (No. JCS-1-89) ("Where shareholders are better able than the corporation to put capital to its most productive use, a tax-based disincentive to distribute earnings creates economic inefficiency.").

78 See Coffee, supra note 56, at 1242 (noting that takeovers can encourage "a higher rate of asset disposition, which probably is in the best interests of shareholders").

79 See supra notes $43-44$ and accompanying text.

80 See generally Grundfest, Management Buyouts and Leveraged Buyouts: Are the Critics Right?, U. PA. L. Alumni J., Winter 1989, at 11, 11-12 (enumerating the benefits of takeovers). But see Reich, supra note 7, at 32 (contending that "[t]here is little evidence [that] . . . mergers have on the average enhanced the profitability or productivity of the merging enterprises").

81 See supra note 3 and accompanying text.

82 Professor Coffee contends that one of the major benefits of takeover activity is that it "constrains managerial self-dealing and inefficiency." Coffee, supra note 56, at 1192. Under the watchful eye of corporate raiders, management must act in the shareholder interest. In an equity financing regime, the incentive is the same. The 
and this will sometimes require making necessary cutbacks. The difference with equity market supervision is that the asset reallocation can occur in a more orderly manner, without the displacement and discontinuity associated with a takeover. Corporate management, the instrument of this asset reallocation, usually has a great deal of human capital invested in the enterprise, ${ }^{83}$ so it may have more concern for the various constituencies involved ${ }^{84}$ when it implements changes.

Equity financing would force corporations to make the necessary adjustments in asset allocation, thereby discouraging hostile takeovers of those corporations which are managed well enough to undertake these adjustments. Thus, the best companies in America will not be vulnerable to takeovers because their stock prices will fairly reflect their profit potential, leaving no residual value for raiders. Dislocation of communities and workers will be more gradual and bearable, and the companies will survive in more efficient form to fight foreign competition.

Conversely, companies that do not respond to market cues on asset allocation will become more vulnerable to attempts to oust management. The market will drive down the stock price of companies which persist in inefficient policies, forcing them to dilute ownership of their assets significantly in order to obtain equity financing. A greater number of shares will trade on the exchange and through arbitrage, can come into hostile hands. A party adverse to management then may be able to launch a proxy fight. ${ }^{85}$ Her chances of winning would be substantial, because she can buy votes on the market or easily solicit votes from other shareholders who have been

\footnotetext{
"watchful eye," however, comprises the shareholders themselves. They wield power over management because of their ability to depress the stock price, making expansion difficult when it is not in the best interests of shareholders.

83 My use of the term "human capital" comes from Professor Clyde Summers. In the context of employee layoffs. he defined "human capital" as the intangible stake one attains through long association with an enterprise. Justice Powell espoused the idea of corporate management having human capital invested in the business and its surrounding community. See Edgar v. MITE Corp., 457 U.S. 624, 646 (1982) (Powell, J., concurring in part). The Borden Company provides a good example of why "human capital" investments must be considered: Borden's management and directors unanimously agreed and contracted to resign in the event of a takeover. See Deutsch, From Cash Cow to Cash Machine, N.Y. Times, Nov. 12, 1989, § 3, at 1, col. 2.

84 The other constituencies include employees, suppliers, pensioners, lower level managers, and members of the community. See Coffee, supra note 56, at 1248.

85 A proxy fight is a means by which stockholders, by soliciting votes, can force a change in corporate policy, oust a board of directors, or initiate a takeover deal. See J. Heard \& H. Sherman, Conflicts of Interest in the Proxy Voting System 28-30 (1987), reprinted in W. CARY \& M. EISENBERG, supra note 43, at 314-15.
} 
made acutely aware of current management's incompetence by the fall in stock price. A hostile party also may profit from a tender offer strategy since the inability of management to reallocate assets leaves an exploitable discrepancy between asset and market value. ${ }^{86}$

Any management that persists in inefficient investment decisions or is completely incompetent will not survive. Thus the problem of entrenched management, like the problem of inefficient asset allocation, largely will be rectified. While hostile takeovers will remain the ultimate threat to poorly run operations, ${ }^{87}$ a process of marketimposed discipline will obviate the need for hostile takeovers to produce quality organizations.

\section{An Equity Financing Regime Would Create Proper Long-Term Performance Incentives}

As shown, the equity financing process beneficially affects those structural problems which create the need for takeovers. This process also imposes important performance incentives which can help United States corporations meet the challenge of foreign competition. American corporations will be more competitive in international markets with the proper long-term performance incentives that accompany equity financing.

Incentives imposed by the current financing system do not reward the best-performing companies in an efficient manner. This becomes clear when examining the incentive structure of the debt financing process. The interest rates that lenders assign to the debt of large, stable corporations do not vary greatly. ${ }^{88}$ This means that there may be no cost of capital variance between companies with significant growth potential and those likely to be stagnant. One reason for this lack of distinction is that a major component of the cost of debt is the prevailing interest rate (prime rate) which is common to all corporate debt regardless of growth potential. Another reason is that risk of failure, the other component of an interest rate, often

86 As the market participants become aware of managerial inadequacies, they will "discount the corporation's shares by a margin sufficient to trigger a takeover." Coffee, supra note 56, at 1203.

87 Judge Friendly, appropriately, called the takeover device "the sharpest blade for the improvement of corporate management." See Friendly, Make Haste Slowly, in Commentaries on Corporate Structure and Government 525, 532 (D. Schwartz ed. 1979); see also Coffee, supra note 56, at 1199 (stating that "it has approached the status of a truism ... that hostile takeovers serve as the primary disciplinary mechanism by which corporate managements are held accountable").

88 See supra notes 52-53 and accompanying text. 
does not differ significantly between growing and stagnant corporations. $^{89}$

Not only does the debt market fail to adequately distinguish growth from non-growth corporations, but also when it makes such a distinction, it often does so in an inefficient way. Inefficient in this context means that lenders often award a lower interest rate to stable corporations, which often hold cash reserves and accumulated assets, than to growth companies, which often require steady influxes of new capital. ${ }^{90}$ This is logical from the lender's perspective, but detrimental to the economy as a whole. When Company X's expected return, discounted for risk of failure, is greater than that of Company $\mathrm{Y}$, it is economically efficient for Company $\mathrm{X}$ to have a lower cost of capital. Yet, in the debt market, where Company $\mathrm{Y}$ is a stable company with greater assets than Company $\mathrm{X}$, exactly the opposite result occurs. This is because lenders focus almost exclusively on the risk of failure, without considering the potential for future growth. ${ }^{91}$

Finally, the debt financing process creates management incentives which are economically detrimental. First, the process rewards inefficient accumulation of assets because a large asset base provides a cushion for banks, resulting in a lower cost of capital. Combined with the tax preference for accumulating and investing earnings ${ }^{92}$ and with the natural predilection of managers to aggrandize their power, ${ }^{93}$ this incentive has the net effect of encouraging the allocation of capital toward assets that ideally should not receive investment capital. In many cases it may be economically beneficial for the corporation to pay a dividend instead of buying the inefficient asset. This would disburse the capital into the competitive marketplace, where investors would allocate the capital to a higher valued use by reinvesting it in corporations pursuing more efficient projects. The flip side of the fact that the debt market encourages asset accumula-

89 See M. Fox, supra note 41, at 270-82; Note, supra note 52, at 1403-04.

90 See generally V. Brudney \& M. Chirelstein, Corporate Finance: Cases and MAterials 331-61 (2d ed. 1979) (noting that lenders are averse to companies who maintain low cash reserves or leverage their assets). The authors partially attribute this caution to the financial failures of the Depression. See id. at 355-56.

91 Professor Coffee makes the same point in a different way, characterizing debt investors as inefficiently risk averse. See Coffee, supra note 56, at 1244-46. A debtholder would be satisfied if the company remained equally profitable from the first day she holds her obligation to the last. Unless the company has reached a state of optimal asset allocation, this preference (and the resulting incentive toward stagnation) is inefficient.

92 See infra notes $141-44$ and accompanying text.

93 See supra notes $45-46$. 
tion is that it discourages taking efficient risks ${ }^{94}$ in anticipation of future returns. Because the major distinguishing factor in pricing debt is a corporation's risk of failure, companies are made commensurately more risk averse. This does not mean that companies will never take risks; management may perceive the potential return as sufficiently high to overcome the increased risk premium built into its cost of debt capital. The net result of this incentive to avoid risk, however, is that a company will demand a higher threshold return before it will invest in a project and will be compelled to forgo other "efficient risk" investment opportunities.

Increased use of equity financing would create economically better performance incentives. First, and probably most importantly, the equity market provides a means of rewarding companies that perform well. The variance among stock prices of companies with similar asset bases is significant; significant in that companies perceived as making better use of their assets are distinguished from their less efficient competitors in the stock market. ${ }^{95}$ This translates into a lower cost of equity capital for companies that efficiently allocate their assets, thereby inducing management to properly control asset use. Second, companies would be forced by the market to realign their investment strategies; shrewd market professionals will reward companies that invest for future returns and discount those which merely accumulate assets. Market investors, unlike commercial bankers, are interested in a company's ability to increase its future payouts, not just to maintain its current level of payments. Thus, the incentive to incur efficient risk is clear. Third, companies will be encouraged to take a long-term perspective on their asset allocation strategies. While this assertion is contrary to the prevailing myth that market traders are short-term oriented, this myth is based more on hype than on coherent analysis. ${ }^{96}$ Equity markets

94 A project represents an "efficient risk" when the expected return on the project, the weighted average of all the possible returns, exceeds the return demanded by the market on projects of similar risk. See R. BREALEY \& S. MYERS, supra note 42 , at $136-40$.

95 The stock market (determinative of equity cost of capital) assigns a price-toearnings ratio ("P/E") to each company's stock. A high $\mathrm{P} / \mathrm{E}$ shows that investors think that the company has good growth opportunities, that its earnings are safe, and that it deserves a low cost of capital. See R. BREALEY \& S. MYERS, supra note 42 , at 60 61. Merck \& Company, a successful drug company with high growth potential, has a $\mathrm{P} / \mathrm{E}$ of 20 , and Ford Motor Company, also a tremendously successful, but less dynamic company, has a P/E of 4. See New York Stock Exchange Composite Transactions, Wall St. J., Jan. 19, 1990, at C4. By contrast, the bond ratings (determinative of debt cost of capital) of the two companies are equivalent.

96 See Hector, Yes, You Can Manage Long Term, Fortune, Nov. 21, 1988, at 64. 
reward long-term investments to the extent that the investments will enhance a corporation's ability to increase future payouts. ${ }^{97}$ In contrast, debt markets discourage long term investments to the extent that they involve risking current ability to maintain payments. As between the equity and debt markets, then, equity markets focus more on the long term, and provide corporate managers with an incentive to manage in that direction.

\section{Methods to Encourage Equity Financing by Corporations}

The capital allocation benefits attributable to equity financing, the performance incentives equity instills, and the respite from hostile takeovers equity provides, are sufficient reasons to consider how the legal system should be altered to encourage equity financing. Currently, the equity market is not used by major, established corporations for financing purposes. Since this disuse can be attributed to disincentives embodied in the tax and securities laws, changes must be made in the regulatory framework. The following discussion suggests two crucial areas for implementing changes: first, the securities laws, which impose significant costs on corporations seeking to make equity issuances, thereby encouraging internal financing; second, the tax laws, which, through the double taxation of dividends and the deductibility of interest payments, discourage equity financing in

\footnotetext{
"Executives complain that Wall Street won't let them look past the here and now. But they're just making lame excuses. The truth is the opposite: Investors love the future." Id. The executives who were consulted admitted a "grudging admiration of the market's prescience." Id. But see Lipton, supra note 1, at 23 ("The advent of the highly leveraged takeover, and the defensive responses to it, have forced companies to focus on short-term profitability rather than on capital investment ....").

97 See Hector, supra note 96, at 68. Fortune published a study of America's twenty largest corporations in which the stock prices were divided into two components: the present value of the next five years' dividends (to reflect short-term prospects), and the residual percentage of the stock price attributable to long-term prospects. The latter category comprised over $80 \%$ of the value of most of the twenty companies' stock. See id. An illustrative example is the Coca-Cola Company, whose five-year dividend payout was worth only $\$ 7$. The stock sold for $\$ 44$, meaning that "roughly $\$ 37$ of Coke's stock price represents the market's estimate of its long-term strength." See id.

Another Fortune study confirms investors' predilection for the long term. Professor Woolridge of Pennsylvania State University examined market reactions after companies announced strategic investments. See id. at 72 . He found that "investors almost always favored them." Id. Specific examples include a $3.58 \%$ sustained rise in Walt Disney stock after the company announced a $\$ 2$ billion investment in EuroDisneyland, which will not likely produce returns until after 2000, and a $2.63 \%$ sustained rise in McDonald's stock, after the chain decided to open restaurants in Sears stores. See it.
} 
favor of debt financing. Admittedly the proposals offered below might be criticized by some as interference in the market and detrimental to efficiency. The response to this attack is that the legal rules as they exist today interfere with the market, and proposals must be offered to remove inefficient impediments to the free flow of capital. ${ }^{98}$

\section{A. Adjustments in the Securities Laws Governing the Issuance of Equity}

\section{Discrepancy in Disclosure Costs between Issuing and Non-Issuing Corporations}

The registration requirements of the Securities Act of 1933 (the "Securities Act") impose significant costs on companies that chose to finance through the equity markets, but not on those which finance internally. The Securities Act thus creates an incentive to retain earnings for internal financing of corporate expansion and a corresponding disincentive to issue stock for external financing. ${ }^{99}$

Section 13 of the Securities Exchange Act of 1934 (the "Exchange Act") requires all registered corporations ${ }^{100}$ to make periodic filings with the Securities and Exchange Commission. ${ }^{101}$ These filings-the annual $10-\mathrm{K}$ form ${ }^{102}$ and the quarterly $10-\mathrm{Q}$ form $^{103}$-are intended to elicit periodic information about the state

98 See Reich, supra note 7, at 40 (stating that those "defenders of free-market orthodoxy" who oppose intervention fail to understand that tax and securities laws as they exist create inefficient incentives for Wall Street's "paper entrepreneurs").

99 Although debt securities, such as bonds and notes also are "securities" for purposes of the securities laws, see 15 U.S.C. $\$ \S 77 \mathrm{a}(1), 77 \mathrm{~b}(1)(1988)$, and are thereby subject to the same disclosure requirements upon issue as equity securities, it is the deductibility of the interest payments on these securities, as on any debt, that gives debt its most important advantage over equity securities.

The purpose of this section is to illustrate how the disclosure requirements of the securities laws impose costs on equity issuances and encourage internal financing. The double taxation of dividends and deductibility of interest, which act as a disincentive to equity financing in favor of debt, will be dealt with in the next section.

100 A corporation is required to be registered under Section 12 of the Exchange Act if it is listed on a national exchange or has assets exceeding $\$ 1$ million and more than 500 stockholders. See 15 U.S.C. $\$ 781(\mathrm{~g})$ (1988).

101 See 15 U.S.C. $\$ 78 \mathrm{~m}$ (1988) (entitled "Periodical and other reports").

102 See 17 C.F.R. $\$ 249.310$ (1989). The form requires the following information: the character of the registrant's business, a statement of capitalization, the salaries of officers and directors, and detailed financial statements. See Amendments to Annual Report Form, Related Forms, Rules, Regulations and Guides, 45 Fed. Reg. 63,630, 63,640-44 (1980).

103 See 17 C.F.R. $\$ 249.308$ a (1989). The form requires the following information: updated financial statements, changes in capitalization since the last 10 - 
of a corporation's affairs. ${ }^{104}$ Certain significant events trigger the obligation to file an additional explanatory $8-\mathrm{K}$ form. ${ }^{105}$ These substantive disclosures must be filed by all large public corporations. Corporations seeking to obtain equity financing, however, are required by the Securities Act to make even further detailed disclosures. ${ }^{106}$ It is this discrepancy between the disclosure required of issuing and non-issuing corporations, and the resulting difference in costs, that provides the focus for analysis. These additional costs imposed on issuing corporations clearly represent disincentives to use the equity market.

Companies registering an issue of securities under the Securities Act must reveal "material changes that have occurred in the affairs of the corporation since the filing of the last $10-\mathrm{K}$ that have not been reported in a subsequent $10-\mathrm{Q}$ or $8-\mathrm{K}$, and . . . the principal purposes for which the corporation intends to use the net proceeds of the issue." 107 Both the "material changes" and the "principal purposes" components of the Securities Act demand disclosures that management may oppose because it does not want to reveal its plans

$\mathrm{K}$ filing, defaults on senior securities, and any matters which were submitted to shareholder vote in the preceding quarter. See New Interim Financial Information Provisions and Revision of Form 10-Q for Quarterly Reporting, 46 Fed. Reg. 12,480, 12,486-88 (1981).

104 See SEC v. Beisinger Indus. Corp., 421 F. Supp. 691 (D. Mass. 1976) (information is designed to assist investors to decide whether to buy, sell, or hold, and to help creditors assess registered corporations), aff'd, 552 F.2d 15 (1st Cir. 1977).

105 See 17 C.F.R. $\$ 249.308$ (1989). A corporation must file an 8-K report upon occurrence of the following events: a change in control, acquisition or disposition of a significant amount of assets, bankruptcy or receivership, or a change in certifying accountants. See Adoption of Amendment to Certain Forms and Related Rules, 42 Fed. Reg. 4424, 4429-30 (1977).

106 The information required of issuing corporations by the Securities Act of 1933,15 U.S.C. $\$ \S 77 \mathrm{a}-77$ aa (1988), includes the general character of the issuer's business, a detailed statement of the company's capitalization, the salaries of the officers and directors, the net proceeds to be derived from the issue and the proceeds of any securities issued in the prior two years, the price at which the company expects to make the offering, any transactions undertaken or planned to which the proceeds of the issue may be applied, detailed financial statements, and copies of all material contracts entered into by the corporation must be attached. See id. at $\S 77$ aa. Compare these stringent requirements with those imposed by the Securities Exchange Act, supra notes $100-05$ and accompanying text.

107 See M. Fox, supra note 42, at 340 . The SEC now recognizes a mechanism by which an issuing corporation can "piggyback" the information contained in its 10-K, 10-Q and 8-K forms onto its Securities Act filings. The new short-form registration form, the S-3, now requires only two types of new information: material changes since the last $10-Q$ and the planned use of the proceeds. See 17 C.F.R. $\$ 239.13$ (1989). As the textual discussion indicates, having to disclose the planned use of the money is an onerous managerial burden. 
to competitors or relinquish any discretion over funds-use decision making. ${ }^{108}$ Furthermore, management may fear incurring liability for any misstatements. ${ }^{109}$ The "material changes" requirement only involves accelerating disclosure of information that would have to be reported on the next quarter's 10-Q form pursuant to Section 13 of the Exchange Act. The additional cost of this early dissemination of information is clearly not onerous. The "principal purposes" requirement, on the other hand, demands significant disclosures that represent direct costs and powerful disincentives to management of the issuing corporation. Because money is fungible, the corporation usually cannot specify one particular project which will be the sole beneficiary of the stock issue proceeds . ${ }^{110}$ Thus, the "principal purposes" requirement demands that management reveal all of its short-term spending plans on a form that will be available for inspection by the public, thereby exposing the corporation's investment strategy to its competitors. ${ }^{111}$

The cost of disclosure by management, which otherwise would prefer to be secretive, is only the first disincentive created by the Securities Act. The second disincentive is much more significant. Under the Securities Act, the corporation must bear a greater risk of liability for false or misleading statements relating to material facts than it does under the Exchange Act. Section 18(a) of the Exchange Act, applicable to all corporations, says that a corporation is liable to one who, "in reliance upon the statement, shall have purchased or sold a security at a price affected by the statement, for damages caused by such reliance, unless [the issuer can show that it] acted in good faith and had no knowledge that the statement was false or mis-

108 See supra notes $43-47$ and accompanying text (describing management's desire to retain unbridled discretion over corporate decision making).

109 See infra notes 112-29 and accompanying text (discussing the increased level of liability imposed on directors and management when the corporation is issuing securities).

110 A corporation is not likely to isolate in its treasury those funds received from a security issuance. Thus, those funds become intermingled with money received through debt financing or generated by operations.

111 This is not to say that this Comment bemoans the level of disclosure required by the Securities Act. It recognizes that this information is needed by the market to properly evaluate an issue. What is objectionable, however, is the discrepancy of disclosure between issuing and non-issuing corporations. This lack of uniformity creates an artificial advantage in favor of internal financing over equity financing. Rather than eliminating disclosure, however, this Comment argues for a uniform level of disclosure for all public corporations, whether issuing or nonissuing. See infra notes $130-40$ and accompanying text (discussing "integrated disclosure"). 
leading."112 Courts strictly construe the reliance element of this cause of action, generally interpreting it to mean that the harmed investor must have actually seen the document containing the misleading statement. ${ }^{113}$ This interpretation makes a class action under Section 18(a) virtually impossible, thus limiting the company's exposure. An action under Rule 10b-5, promulgated under Section 10(b) of the Exchange Act, ${ }^{114}$ is also available to aggrieved parties. ${ }^{115}$ Such an action, however, requires a showing of scienter, ${ }^{116}$ a requirement that insulates the corporation. ${ }^{117}$

The Securities Act, on the other hand, involves greater risk for the issuing corporation. Section 11 of the Securities Act creates a cause of action for anyone purchasing a security the registration statement for which either (1) omits a fact required to be stated or (2) contains a false or misleading statement. ${ }^{118}$ Neither reliance nor scienter need be shown, and no affirmative defense is available to the issuing corporation. ${ }^{119}$ This Section, generous to plaintiffs, makes a

11215 U.S.C. \& 78r(a) (1988).

113 See Gross v. Diversified Mortgage Investors, 438 F. Supp. 190, 195 (S.D.N.Y. 1977). Section 18 provides a remedy for damages caused by reliance on a misleading statement contained in a document or report filed with the SEC. See Cramer v. General Tel. \& Elec. Corp., 582 F.2d 259, 269-70 (3rd Cir. 1978) (deciding that a plaintiff must allege actual reliance on false and misleading statements, in particular, reports or documents on file with the SEC), cert. denied, 439 U.S. 1129 (1979); Heit v. Weitzen, 402 F.2d 909, 916 (2d Cir. 1968), (holding that constructive reliance is not sufficient), cert. denied, 395 U.S. 903 (1969).

114 See 15 U.S.C. § 78(b) (1988).

115 Rule 10b-5 makes it illegal:

(a) To employ any device, scheme, or artifice to defraud;

(b) To make any untrue statement of a material fact or to omit to state a material fact necessary in order to make the statements made, in the light of the circumstances under which they were made, not misleading, or

(c) To engage in any act, practice, or course of business which operates or would operate as a fraud or deceit upon any person, in connection with the purchase or sale of any security.

17 C.F.R. § 240.10b-5 (1989).

116 See Aaron v. SEC, 446 U.S. 680, 691 (1980) (holding that "scienter is an element of a violation of $\$ 10(\mathrm{~b})$ and Rule $10 \mathrm{~b}-5$, regardless of the identity of the plaintiff or the nature of the relief sought").

117 The corporation, along with its officers and directors, is protected by the scienter requirement of a $10 \mathrm{~b}-5$ action from liability for negligent or inadvertent misstatements. See Aaron, 446 U.S. at 689-93 (stating that scienter involves intent, not mere negligence); Ernst \& Ernst v. Hochfelder, 425 U.S. 185, 193 (1976) (defining scienter as "intent to deceive, manipulate, or defraud").

118 See 15 U.S.C. $\$ 77 \mathrm{k}(1988)$.

119 See id. at $\S 77 \mathrm{k}(\mathrm{a})$. With regard to section 11 (a), "Congress created express liability regardless of the defendant's fault." Hochfelder, 425 U.S. at 200. The issuer is 
class action feasible and liability absolute. ${ }^{120}$ Clearly, the increased risk imposed by Section 11 of the Securities Act as compared to Section 18 of the Exchange Act represents a significant cost and creates a disincentive for equity financing. ${ }^{121}$

Managers' and directors' risk of liability is also much greater if the corporation elects to make an equity issuance. Under the Securities Act, a corporation is absolutely liable for registration misstatements. ${ }^{122}$ In addition, the burden of proof shifts when a corporation registers an equity issue under the Securities Act. Under Section 18(a) of the Exchange Act, applicable to all registered corporations, a plaintiff must prove that the defendant director or manager caused the misleading statement to be made. ${ }^{123}$ Similarly, under the universally applicable Rule 10b-5 action, a plaintiff has the burden of proving that the officer or director "aided or abetted" in making the false statement. ${ }^{124}$ But, when a corporation registers an issuance of stock under the Securities Act, each director and officer is jointly and severally liable with the strictly-liable corporation unless she can prove the elements of the "due diligence" defense. This defense requires that the officer or director show that she conducted a sufficiently thorough investigation into the veracity of the facts, and that based on this investigation, she reasonably' believed the statements were true. ${ }^{125}$

Shifting the burden of proof onto the officers and directors increases their risk of liability, translating into either a direct exposure cost or an indirect cost in the form of more rigorous (and often

absolutely liable for misleading statements contained in the registration statement. See id.

120 Professor Fox says that Section 11 facilitates suits because:

(1) For a period of one year after the filing, plaintiffs need not show actual reliance, which allows for class actions;

(2) The plaintiff does not have to show scienter, and there are no defenses allowed, so liability is virtually absolute. M. Fox, supra note 41 , at 344 .

121 See H.R. REP. No. 85, 73d Cong., 1st Sess. 9 (1933) (reporting that Congress meant Section 11 to place "a heavier legal liability" on issuing corporations).

122 See 15 U.S.C. $\$ 77 \mathrm{k}$ (a) (1988) (Section 11 of the Securities Act); supra notes 118-20 and accompanying text (discussing how Section 11 creates absolute liability for material omissions or false or misleading statements on registration statements).

123 See 15 U.S.C. § 78r(a) (1988) ("Any person who shall make or cause to be made" a misstatement shall be liable.).

124 See Aaron v. SEC, 446 U.S. 680, 684 (1980) (stating that plaintiff had to show that defendant "violated or aided and abetted violations" of Rule 10b-5).

125 See 15 U.S.C. § 77k(b)(3) (1988); see also Ernst \& Ernst v. Hochfelder, 425 U.S. 185, 208 (1976) (stating that officers and directors are allowed a defense against civil liability "based on the exercise of reasonable investigation and a reasonable belief that the registration statement was not misleading"). 
redundant) investigation and higher insurance premiums. The officers and directors-the financing decision makers-are inclined to avoid this cost and opt for internal financing.

The legislative history of Section 11 reveals that, as a whole, the liability scheme of that section is designed to induce all participants in the issuing process to expose the true facts about the issuing corporation. ${ }^{126}$ In large part throughout its history, Section 11 has succeeded in assuring the veracity of registration statement disclosures, ${ }^{127}$ albeit at the possible expense of frightening potential issuers from the equity market. Until quite recently, with the enactment of reforms aimed at integrated disclosure, ${ }^{128}$ the imposition upon underwriters of a due diligence responsibility provided added insurance that disclosures were complete and accurate. Underwriters saddled with potential liability undertook thorough, independent investigations of the issuer. This practice, however, is waning as integrated disclosure works its way into the securities system. ${ }^{129}$ The SEC's experiment in integrated disclosure has the potential to remove some of the disincentives for equity financing contained in the disclosure/liability scheme of the federal securities laws. If poorly implemented, however, the program could have the consequence of causing a greater number of incomplete or inaccurate registration statements to be filed. This potential adverse effect would undercut the goal of insuring complete disclosure. Hence, the proper implementation of this program, discussed next, is crucial.

\section{Levelling the Playing Field Through Integrated Disclosure}

In the 1980s the SEC adopted a number of rules and regulations

126 See H.R. REP. No. 85, supra note 121, at 3 (explaining that the legislation sought "full disclosure of every essentially important element attending the issue of a new security").

127 See generally M. Fox, supra note 41, at 339-67. A recurrent theme in Fox's argument in favor of integrated clisclosure is that the strict standards imposed by Section 11 encourage issuers, underwriters, and the lawyers for both to take the utmost care in preparing registration statements.

128 See infra notes $130-40$ and accompanying text.

129 After the integrated disclosure system was put in place, the Securities Industry Association undertook a survey which found that only $9 \%$ of underwriters believed they were performing as nuch due diligence as before integrated disclosure. See Nicholas, The Integrated Disclosure System and Its Impact Upon Underwriters' Due Diligence: Will Investors Be Protected?, 11 SEc. Rec. L.J. 3, 33 \& n.92 (1983). The survey also revealed that only $13 \%$ of companies engaged underwriters in preparing 10-Ks, and that the percentage was significantly lower for both 10-Qs and 8-Ks. See id. 
designed to lower the cost to companies making public offerings. The integrated disclosure program, as these changes are called, is comprised of three components. First, the SEC now allows large corporations to use a short Form S-3 as its registration form. ${ }^{130}$ The $\mathrm{S}-3$ incorporates by reference the corporation's latest $10-\mathrm{K}$ and subsequently filed $10-\mathrm{Qs}$ and $8-\mathrm{Ks}$, which reduces the professional fees that once were involved in preparing a voluminous set of new documents. Second, the SEC no longer reviews most S-3 registration statements, and such statements often become effective after only two days. ${ }^{131}$ This accelerated process eliminates costly delay. Third, a shelf registration technique allows a corporation to issue a series of securities over a two year period without having to refile. ${ }^{132}$ Rule $415^{133}$ allows the issuer to name several underwriters on the registration statement, any of which will be permitted to compete for each series of the issuance. Hence, the company effectively can maintain an inventory of securities that it can sell whenever it wishes and to whichever investment bank will offer it the best terms. ${ }^{134}$

The integrated disclosure program removes some equity financing disincentives. The mechanical costs of producing new documents is greatly reduced, and the accompanying ability to time an offering is attractive to companies. Major disincentives, however, still remain. A corporation making an equity offering must subject itself to the Securities Act's increased exposure to liability. Issuing corporations also still must make "principle purpose" disclosures because the $\mathrm{S}-3$ form does not dispose of the requirement that the issuer reveal how it plans to use the sale proceeds.

Moreover, integrated disclosure has the disadvantage of undercutting the multi-leveled process that ensures the integrity of regis-

130 See M. Fox, supra note 41, at 350-51 (citing Securities Act Release No. 6383).

131 See id. at 351.

132 See id. at 351-52. The issuer need not amend its filing unless there is a fundamental change in the information initially reported. See 17 C.F.R. $\$ 230.415$ (1989). This updating requirement is consistent with a longstanding SEC policy against allowing the sale of securities based on old information. See, e.g, In re Shawnee Chiles Syndicate, 10 S.E.C. 109, 113-14 (1941) (holding that Securities Act \$ 6(a) suggests a policy against stale information).

13317 C.F.R. § 230.415 (1989).

134 The effect of Rule 415 is to permit an issuer that wishes to sell some or all of the registered securities at any point during the two year period to contact the several managing underwriters named in the registration statement, determine which underwriter will give it the best terms, and offer the security to the market through that underwriter in a matter of hours.

Fox, Shelf Registration, Integrated Disclosure, and Underwriter Due Diligence: An Economic Analysis, 70 VA. L. REv. 1005, 1005 n.4 (1984). 
tration disclosures; ${ }^{135}$ expediting the process of marketing securities to the public increases the chances that misleading registration statements will be filed. The SEC's chosen path for making the securities markets more accessible thus may have resulted in reducing the mandated level of disclosure. lndeed, although the SEC denies that underwriter investigation has become less intense, the facts show otherwise. ${ }^{136}$

There need not be this tradeoff between removing impediments from the market and loosering disclosure requirements. The SEC should seek to merge the disclosure requirements of the Securities Act with those of the Exchange Act, while aiming for the higher standard of disclosure imposed by the Securities Act. ${ }^{137}$ This would involve requiring all corporations, along with their officers and directors, to make more complete regular Exchange Act disclosures and accept a higher risk of liability. The objective would be to level the playing field between those companies seeking access to the equity market and those still choosing to finance internally. This equalization would result in somewhat higher transaction costs for all public corporations, but it also should produce a higher quality of information for the efficient market too digest, and corporations would benefit in the aggregate.

Merging the two acts would require applying the liability standards imposed by the Securities Act to all corporations. Accordingly, officers and directors of a corporation financing internally would be liable for disclosure violations under the stringent requirements of the Securities Act. In other words, if an officer or director of a violating company could not meet the due diligence defense, she would be open to liability. ${ }^{138}$

The basic objectives of the merger proposal are to impose the same level of liability upon, and require the same level of disclosure

135 See supra notes $118-21$ and accompanying text.

186 See supra note 129 and accompanying text.

137 Professor Fox is a strong advocate of total integration of the disclosure required of issuing corporations by the Securities Act with that required of all listed corporations by the Securities Exchange Act. See M. Fox, supra note 41, at 358-67; see also Fox, supra note 134, at 1009 (stating that "the SEC should develop ways to put the same kinds of pressures on issuers when they prepare Exchange Act periodic reports as underwriters historically placed on them when the issuers prepared Securities Act registration statements").

138 Holding officers and directors liable for failure to meet due diligence standards is consistent with Delaware Supreme Court policy. See Smith v. Van Gorkom, 488 A.2d 858, 893 (Del. 1985) (concluding that the defense that an action was a "business judgment" does not protect those who fail to do the necessary research). 
from, all registered corporations, whether or not they make public offerings. The objectives can be accomplished practically by utilizing the 10-K forms corporations are required to file annually and the 10$Q$ forms they must file quarterly. Directors, officers, and underwriters would have to certify the information contained in the forms and subject themselves to liability for disclosure violations. In addition, the forms might be altered to ask some questions pertaining to shortterm financing plans, as this information would be required by the Securities Act, so as to eliminate disclosure discrepancies. Most actions for a disclosure violation could be brought derivatively, with the incentive to do so being the potential under state law for attorney's fees. ${ }^{139}$ Ideally, an efficient enforcement mechanism will develop, as it has in the case of Section 16(b) violations. ${ }^{140}$

\section{B. Removal of the Tax Incentive Favoring Debt Financing Over Equity Financing}

Properly adjusting the securities laws would go a long way toward removing the disincentives to equity financing in favor of internal financing by removing the additional costs imposed on equity issuances under the current regulatory regime. This adjustment, however, would correct only part of the problem. The inefficient incentives favoring debt financing over equity financing lie not in the securities laws, but in the tax law. Hence, the tax laws also must be adjusted to encourage equity financing.

The tax law currently favors debt financing by allowing deductibility of corporate interest payments. Section 163(a) of the Internal Revenue Code states that for corporations, "[t]here shall be allowed as a deduction all interest paid or accrued within the taxable year on indebtedness." "141 By contrast, there is no such deduction for distri-

139 Under Delaware law, the corporation must pay the costs and attorneys' fees for any successful plaintiff in a derivative action. See, e.g., Allied Artists Pictures v. Baron, 413 A.2d 876, 878 (Del. 1980) (awarding costs and attorneys' fees to successful plaintiff in derivative suit); Gottlieb v. Heyden Chem. Corp., 105 A.2d 461, 462 (Del. 1954) (same). Commentators realize that without attorneys' fees paid by the corporation, "few shareholders would pay attorneys' fees out of their own pockets to finance a suit that .. . normally holds only slight and indirect benefit for the plaintiff." W. CARY \& M. EISENBERG, supra note 43, at 1018.

140 Under Section 16(b) of the Securities Exchange Act of 1934, when a corporate insider, or $10 \%$ holder, profits by purchasing and selling the company's stock within a six month period, the company may recover the profits. See 15 U.S.C. $\S 78 p$ (b) (1988). There are law firms, especially in the Southern District of New York where 16(b) actions are brought, that specialize in tracking the purchases and sales of insiders and large shareholders.

141 I.R.C. \& 163(a) (1982). 
bution of dividends. In general, corporate profits are taxed once at the entity level when they are earned and reported by the corporation, and again under Section 301 when they are distributed to the owners. ${ }^{142}$

The deductibility of interest payments compared to the double taxation of distributed corporate earnings creates an inefficient advantage for debt financing. Economically, interest on debt and dividend payments are equivalents from the corporate perspectiveboth represent the cost of funds. The tax code, however, chooses to draw a distinction, providing: a debt subsidy worth in dollar terms the amount of interest payments multiplied by the marginal tax rate. The consequences of this subsidy are powerful enough nearly to eradicate the equity market as a viable source of corporate financing. ${ }^{143}$ The greater tax burden on equity obviates all of the advantages of equity financing described earlier in this paper, the most important of which is efficient capital allocation. The efficient equity market cannot provide economic advantages unless it is used, and it will not be used as long as the competing supplier of external corporate funds, the debt market, is given a significant (34\%) tax advantage. ${ }^{144}$

There are three ways to remedy the artificial debt advantage, thereby rendering the decision between debt and equity one which corporations can make on the basis of real economic factors. The first alternative is to make interest on corporate debt nondeductible. This would involve eliminating Section 163(a), which expressly allows the deduction, and amending Section 162 to state that interest payments are not to be construed as "ordinary and necessary business expenses." ${ }^{45}$ This approach derives from the premise that the

142 See I.R.C. $\$ 301$ (c) (1982) (providing that dividends are to be included in a shareholder's gross income). Influential commentators have proposed that the individual and corporate levels of tax on a corporation's earnings be integrated so as to eliminate the double taxation on dividends. See Surrey, Reflections on "Integration" of Corporation and Individual Incomes, 28 NAT'L TAX J. 335, 336-38 (1975); Warren, The Relation and Integration of Individual and Corporate Taxes, 94 HARv. L. REv. 717, 736-38, $772-75$ (1981).

143 See Kaufman, supra note 5, at 23 (stating that double taxation of dividends is why companies prefer debt to equity); Murray, supra note 16, at A18 (noting that businessmen and lawmakers worry that the tax code encourages debt by allowing companies to deduct interest payments but not their dividends).

144 See I.R.C. $\$ 11(\mathrm{~b})(1)(\mathrm{C})(\mathrm{CCH} 1989)$ (the marginal tax rate on corporate income in excess of $\$ 75,000$ per year is $34 \%$ ).

145 See I.R.C. $\S 162$ (a) (1982). Interest payments might be construed as deductible business expenses unless such payments are expressly excluded from $\S 162$. 
interest paid deduction is a tax expenditure, and the government should not subsidize debt incurrence.

The second alternative to rationalize the choice between debt and equity is to create a deduction from corporate income for dividends paid. ${ }^{146}$ The Code already contains a similar deduction, as Section 247 allows a corporate-level deduction for dividends paid on certain preferred stock of public utilities. ${ }^{147}$ The creation of a generally applicable dividend deduction would involve writing a new code section and abandoning, in large measure, the concept of double taxation of corporate earnings, because most earnings are either invested or distributed. Under the present tax system, invested earnings are either capitalized and depreciated under Section $263^{148}$ or currently deductible under Section 162. Creating a deduction for distributed earnings as dividends paid thus would leave little to be taxed at the corporate level.

Creation of a dividends paid deduction derives from a more logical premise than does removing the deduction for interest payments. First, both dividends and interest expenses are, after all, business expenses from the corporate perspective. Dividends are the price the company must pay to obtain funds from the equity market, and interest is the price it must pay to borrow funds from the debt market. Second, creating the new deduction would more likely result in the benefits described earlier. Specifically, takeovers would be discouraged because stock prices would rise in accordance with the increase in aggregate dividend rates.

Unfortunately, the creation of a new deduction would likely have adverse, possibly debilitating, revenue consequences. The revenue loss associated with a dividends paid deduction would be mitigated by the increased taxed assessed at the shareholder level, as the rate of dividend payments increased. Furthermore, eventually there would be a revenue gain from the general improvement in asset allocation, resulting in better corporate performance and more aggregate earnings to be distributed. Nevertheless, these arguments are

146 This is generally the approach favored by Federal Reserve Board Chairman Alan Greenspan. See Wessel, Greenspan Wants to Keep Deductibility of Interest Payments by Corporations, Wall St. J., Jan. 27, 1989, at A3, col. 1. Greenspan wants to "reduce the taxes shareholders pay on dividends." Id. His ultimate objectives are to "remove the tax incentives for companies to rely on debt," and to "encourage equity financing." Id. The stock market rose over 25 points on the day Greenspan announced his position. See Stock Market Data Bank, Wall St. J., Jan. 27, 1989, at C2, col. 4.

147 See I.R.C. § 247 (1982).

148 See I.R.C. $\$ 263$ (1982). 
not likely to convince a deficit-conscious legislature to enact a dividends paid deduction. ${ }^{149}$

The third alternative for correcting the debt advantage is a compromise. A partial dividends paid deduction (say, 50\%) could be combined with a commensurately limited interest paid deduction ${ }^{150}$ under Section 163. This would eliminate tax considerations in the rhoice between debt and equity financing, thus allowing the corporation to choose on the basis of real economic factors. Forcing corporate choice based on real economic factors should increase both the use of equity financing and the corresponding capital allocation benefits associated with equity.

\section{Conclusion}

At the time of this writing, it appears as if market forces are turning away from the debt binges of the 1980s. The "junk bond" market has collapsed, and with it has fallen the firm responsible for its creation. ${ }^{151}$ As a result, sorne Wall Street executives are predicting a new era based on conservative practices and a renewed fondness for equity financing. ${ }^{152}$ These developments, however, do not obviate the need to change the regulatory structure to encourage equity financing by public corporations. The reasons enumerated in this Comment for encouraging equity financing are too important to be

149 Tax experts at the Treasury Department are working on a plan to eliminate the double taxation of dividends. To offset the revenue loss of such a tax break, they are also considering "changes that might boost some corporations' taxes." See Murray, supra note 16, at A18. One option being looked at would not only eliminate the double taxation of dividends. but also tax interest payments made to pension funds and other tax-exempt entities. See id.

150 Treasury Secretary Nicholas Brady has proposed a compromise approach. See Birnbaum \& Duke, Tax Writers Move on Plan to Curb LBOs, Wall St. J., Jan. 26, 1989, at A2, col. 2 (stating that Brady espouses "a two-pronged plan that would curtail tax benefits for corporate debt while creating a tax break for dividends"). However, Federal Reserve Chairman Alan Greenspan opposes the compromise, arguing that "[t]inkering with the interest deduction has too many potential adverse side effects." Wessel, supra note 146 , at A3.

Professor Reich advocates this "partial deductibility" approach. He suggests allowing a deduction for all corporate payouts not in excess of the Federal Funds rate, plus two percentage points. See Reich, supra note 7, at 40. Chairman Greenspan objects to imposing what amounts to a tax penalty upon risky loans, saying, "We must resist the temptation to seek. to allocate credit to specific uses through the tax system." Wessel, supra note 146, at A3.

151 See Sicinolf, Power, Cohen \& Guenther, Rise and Fall: Wall Street Era Ends As Drexel Burnham Decides to Liquidate, Wall St. J., Feb. 14, 1990, at A1, col. 6; see also Miller, Gleizes \& Bradburn, The Downfall of Drexel, Newsweek, Feb. 26, 1990, at 50.

152 See Sicinolf, Power, Cohen \& Guenther, supra note 151, at A1; Lowenstein, Firms Expected to Rely Much More on Stock Sales, Wall St. J., Feb. 14, 1990, at A6, col. 1. 
left to chance, and a fully effective regime cannot be implemented without legislative changes.

It is important to recognize that the most novel and significant challenges facing America in the 1990s and beyond are economic in nature. Lawmakers must be cognizant of the long-range strategic effects of the legislation they propound in response to these challenges. If they do not adequately study the economic effects of the legal incentives they create, their negligence will come back to haunt future generations, as mistakes made by past decision makers are haunting America today. 
